Research Note

\title{
Effect of Types of Biosolids and Cattle Manure on Desert Grass Growth
}

\author{
Ricardo Mata-González, ${ }^{1}$ Ronald E. Sosebee, ${ }^{2}$ and Changgui Wan ${ }^{3}$ \\ Authors are ${ }^{1}$ Ecologist, MWH Americas, Inc, Fort Collins, CO 80525; and ${ }^{2}$ Professor and ${ }^{3}$ Research Associate, \\ Department of Range, Wildlife, and Fisheries Management, Texas Tech University, Lubbock, TX 79409.
}

\begin{abstract}
We compared the effect of applying anaerobically produced biosolids, lime-stabilized biosolids, and cattle manure on the production of blue grama (Bouteloua gracilis [HBK] Lag. ex Steud.) and black grama (B. eriopoda [Torr.] Torr.) grown in pots with moderate soil water content. We also compared the physicochemical and bacteriological composition of these 3 amendments. All amendments produced similar increases in plant growth, despite their differences in plant nutrient concentrations, as a result of limitations in soil water. Heavy metal levels in biosolids were within the US Environmental Protection agency limits for Class A and Class B biosolids, but were higher than in manure. In contrast, pathogen levels were lower in biosolids than in manure. Application of biosolids and cattle manure increased the production of both grasses and may have equivalent effects under typical climatic and soil conditions of semiarid rangelands.
\end{abstract}

\section{Resumen}

Comparamos el efecto de la aplicación de biosólidos producidos anaeróbicamente, biosólidos producidos por aplicación de cal, y estiércol bovino en la producción de navajita azul (Bouteloua gracilis [HBK] Lag. ex Steud.) y navajita negro (B. eriopoda [Torr.] Torr.) creciendo en macetas con nivel moderado de humedad. También comparamos la composición físico-química y bacteriológica de estos tres productos orgánicos. Los tres productos orgánicos produjeron un incremento similar en el crecimiento de plants a pesar de sus diferencias en niveles de nutrientes, debido a limitaciones en humedad. Los metales pesados en biosólidos estuvieron dentro de los límites establecidos por la US Environmental Protection Agency para biosólidos de clase A y B, pero fueron mas altos que en estiércol. En contraste, los niveles de patógenos fueron mas bajos en biosólidos que en estiércol. La aplicacion de biosólidos y estiércol incremento la producción de los dos pastos y pueden tener efectos equivalentes bajo condiciones climáticas y edáficas de pastizales semiáridos.

Key Words: black grama, blue grama, Bouteloua eriopoda, Bouteloua gracilis, fecal coliform bacteria, heavy metals

\section{INTRODUCTION}

Biosolids are nutrient-rich organic compounds that result as a by-product of municipal wastewater treatment. The beneficial use of biosolids as soil amendment and the enhancement of rangeland plant production have been documented (Fresquez et al. 1990; Jurado and Wester 2001; Mata-González et al. 2002, 2004). Biosolids, however, require certain quality standards to prevent contamination. Class B biosolids, with low levels of pathogens and heavy metals, are required for application in rangelands, agricultural lands, and reclamation sites. Class A biosolids, with even lower levels of pathogens and heavy metals, are required for application in lawns or home gardens (USEPA 1994, Table 1).

Biosolids and partial funding were provided by MERCO Joint Venture LLP. Assistance from Pedro Jurado Guerra, David Wester, Carlos Villalobos, Corey Moffet, and Joanna Hahm is gratefully acknowledged. This is contribution T-9-1051 of the College of Agricultural Sciences and Natural Resources, Texas Tech University.

Correspondence: R. Mata-González, MWH Americas, Inc, 1825 Sharp Point Drive, Suite 118, Fort Collins, C0 80525. Email: ricardo.mata-gonzalez@mwhylobal.com

Manuscript received 5 October 2005; manuscript accepted 31 August 2006.
Different municipal treatment methods may affect the composition and the fertilizing characteristics of the biosolids (USEPA 2000). Many studies on rangeland plants have used biosolids obtained by anaerobic digestion (Fresquez et al. 1990; Jurado and Wester 2001; Mata-González et al. 2002, 2004). Biosolids obtained by lime stabilization have rarely been used in studies despite their abundance (USEPA 2000).

Biosolids commonly have total $\mathrm{N}$ content of $3 \%-5 \%$, which is comparable to animal manures (Ajwa and Tabatabai 1994). Although their fertilizing effect could be similar, there is limited information (Moss et al. 2002) directly comparing the benefits of biosolids and manure on rangeland plant growth. Such information is important to associate the effect of biosolids to that of the more conventional and socially accepted cattle manure (Moss et al. 2002).

In this study we compared the effect of applying anaerobically produced biosolids, lime-stabilized biosolids, and cattle manure as soil amendments on aboveground production of blue grama (Bouteloua gracilis [HBK] Lag. ex Steud.) and black grama (Bouteloua eriopoda [Torr.] Torr.), grown in pots within a rainout shelter. Our hypothesis was that the 3 amendments would produce similar effects on desert grass growth. We also compared the amendments in terms of some physicochemical 
Table 1. Physicochemical and bacteriological components (mean \pm SEM) of 2 types of biosolids and cattle manure and USEPA (1994) limits for heavy metals and pathogens in Class $A$ and $B$ biosolids. Different letters indicate amendment differences $(P<0.05)$ for a particular component.

\begin{tabular}{|c|c|c|c|c|c|}
\hline Component & $\begin{array}{c}\text { Anaerobically } \\
\text { produced biosolids }\end{array}$ & $\begin{array}{l}\text { Lime-stabilized } \\
\text { biosolids }\end{array}$ & Cattle manure & $\begin{array}{l}\text { USEPA limits } \\
\text { for class B }\end{array}$ & $\begin{array}{l}\text { USEPA limits } \\
\text { for class A }\end{array}$ \\
\hline $\operatorname{TKN}^{1}\left(g \cdot \mathrm{kg}^{-1}\right)$ & $49.2 \pm 2.2 \mathrm{a}$ & $50.6 \pm 1.8 \mathrm{a}$ & $12.1 \pm 0.5 b$ & $\mathrm{~N} / \mathrm{A}$ & $N / A$ \\
\hline$P\left(g \cdot \mathrm{kg}^{-1}\right)$ & $1.6 \pm 0.1 \mathrm{a}$ & $1.4 \pm 0.1 \mathrm{a}$ & $0.3 \pm 0.1 \mathrm{~b}$ & $\mathrm{~N} / \mathrm{A}$ & $\mathrm{N} / \mathrm{A}$ \\
\hline$K\left(g \cdot \mathrm{kg}^{-1}\right)$ & $1.6 \pm 0.1 \mathrm{a}$ & $1.4 \pm 0.1 \mathrm{a}$ & $4.2 \pm 0.3 \mathrm{~b}$ & $\mathrm{~N} / \mathrm{A}$ & $\mathrm{N} / \mathrm{A}$ \\
\hline $\mathrm{Ca}\left(\mathrm{g} \cdot \mathrm{kg}^{-1}\right)$ & $31.4 \pm 2.3 \mathrm{a}$ & $41.6 \pm 4.0 \mathrm{~b}$ & $19.0 \pm 0.7 c$ & $\mathrm{~N} / \mathrm{A}$ & $\mathrm{N} / \mathrm{A}$ \\
\hline$M g\left(g \cdot \mathrm{kg}^{-1}\right)$ & $7.7 \pm 0.2 \mathrm{a}$ & $7.1 \pm 0.3 \mathrm{a}$ & $2.7 \pm 0.1 \mathrm{~b}$ & $\mathrm{~N} / \mathrm{A}$ & $N / A$ \\
\hline$S\left(g \cdot \mathrm{kg}^{-1}\right)$ & $16.0 \pm 0.5 \mathrm{a}$ & $17.6 \pm 1.1 \mathrm{a}$ & $2.0 \pm 0.1 \mathrm{~b}$ & $\mathrm{~N} / \mathrm{A}$ & $N / A$ \\
\hline $\mathrm{Na}\left(\mathrm{g} \cdot \mathrm{kg}^{-1}\right)$ & $1.7 \pm 0.4 \mathrm{a}$ & $2.6 \pm 0.4 \mathrm{~b}$ & $2.3 \pm 0.1 \mathrm{~b}$ & $\mathrm{~N} / \mathrm{A}$ & $\mathrm{N} / \mathrm{A}$ \\
\hline $\mathrm{EC}\left(\mathrm{dS} \cdot \mathrm{m}^{-1}\right)$ & $9.9 \pm 0.9 \mathrm{a}$ & $12.5 \pm 0.9 b$ & $4.3 \pm 0.3 \mathrm{c}$ & $\mathrm{N} / \mathrm{A}$ & $\mathrm{N} / \mathrm{A}$ \\
\hline pH & $7.3 \pm 0.1 \mathrm{a}$ & $7.3 \pm 0.1 \mathrm{a}$ & $6.9 \pm 0.1 \mathrm{~b}$ & $\mathrm{~N} / \mathrm{A}$ & $\mathrm{N} / \mathrm{A}$ \\
\hline Water $\left(\mathrm{g} \cdot \mathrm{kg}^{-1}\right)$ & $798.1 \pm 3.0 \mathrm{a}$ & $802.0 \pm 3.0 \mathrm{a}$ & $711.8 \pm 8.7 b$ & $\mathrm{~N} / \mathrm{A}$ & $\mathrm{N} / \mathrm{A}$ \\
\hline $\operatorname{Mn}\left(\mathrm{mg} \mathrm{kg}^{-1}\right)$ & $573.0 \pm 7.4 \mathrm{a}$ & $567.0 \pm 22.6 \mathrm{a}$ & $133.6 \pm 4.5 b$ & $\mathrm{~N} / \mathrm{A}$ & $\mathrm{N} / \mathrm{A}$ \\
\hline $\mathrm{Ni}\left(\mathrm{mg} \cdot \mathrm{kg}^{-1}\right)$ & $44.4 \pm 3.3 \mathrm{a}$ & $54.5 \pm 4.0 \mathrm{~b}$ & $6.0 \pm 0.3 \mathrm{c}$ & 420 & 420 \\
\hline $\mathrm{Cd}\left(\mathrm{mg} \cdot \mathrm{kg}^{-1}\right)$ & $3.3 \pm 0.2 \mathrm{a}$ & $3.6 \pm 0.3 \mathrm{a}$ & $3.6 \pm 3.4 \mathrm{a}$ & 85 & 39 \\
\hline $\mathrm{Zn}\left(\mathrm{mg} \cdot \mathrm{kg}^{-1}\right)$ & $1258 \pm 48.3 \mathrm{a}$ & $1105 \pm 65.7 \mathrm{a}$ & $84 \pm 14.8 b$ & 7500 & 2800 \\
\hline $\mathrm{Pb}\left(\mathrm{mg} \cdot \mathrm{kg}^{-1}\right)$ & $221.2 \pm 3.5 \mathrm{a}$ & $211.8 \pm 9.4 \mathrm{a}$ & $7.3 \pm 0.8 b$ & 840 & 300 \\
\hline $\mathrm{Cu}\left(\mathrm{mg} \cdot \mathrm{kg}^{-1}\right)$ & $920.6 \pm 48.9 \mathrm{a}$ & $762.0 \pm 53.4 b$ & $25.2 \pm 2.6 c$ & 4300 & 1500 \\
\hline \multicolumn{6}{|c|}{ Fecal coliform bacteria } \\
\hline$\left(\mathrm{CFU} \cdot \mathrm{g}^{-1}\right)$ & $<1 \times 10^{6} \mathrm{a}$ & $<1 \times 10^{6} \mathrm{a}$ & $>50 \times 10^{6} \mathrm{~b}$ & $<2 \times 10^{6}$ & $<1000$ \\
\hline
\end{tabular}

${ }^{1}$ TKN indicates total Kjeldahl nitrogen; EC, electrical conductivity; CFU, colony-forming units.

and bacteriological components and their potential benefits and disadvantages for land application.

\section{MATERIALS AND METHODS}

This study was conducted at the Sierra Blanca Ranch, Texas, where blue grama and black grama are important components of desert grasslands. This area is part of the Chihuahuan Desert, with annual precipitation of $310 \mathrm{~mm}$ concentrated from July to September. Plants of both species with 4 tillers were collected from the field in May 2000 and transplanted into plastic pots (volume $14.7 \mathrm{l}$, depth $30 \mathrm{~cm}$, and diameter $25 \mathrm{~cm}$ ) containing Armesa taxadjunct fine sandy loam soil, which is a fine, loamy, mixed, thermic Ustic Haplocalcid. This soil holds about $190 \mathrm{~g}$ of water per $\mathrm{kg}$ of soil at field capacity, has a $\mathrm{pH}$ of 7.5, a TKN level of $496 \mathrm{mg} \cdot \mathrm{kg}^{-1}$, and an organic matter content of $7 \mathrm{~g} \cdot \mathrm{kg}^{-1}$ (more details in Mata-González et al. 2004). The soil used in the experiment was collected from $0-30 \mathrm{~cm}$ depth, air dried, and passed through a $0.5-\mathrm{cm}$ sieve to provide a homogeneous rooting medium and to facilitate water distribution in the pot.

The plants were grown under a semicylindrical rainout shelter covered with greenhouse plastic film. The plants were regularly irrigated to achieve establishment for 2 months before initiating the biosolids treatments. Anaerobically produced biosolids, lime-stabilized biosolids, and cattle manure were applied on the soil surface of the pots in early July 2000 at rates of 0 (control), 34, and $90 \mathrm{dry} \mathrm{Mg} \cdot \mathrm{ha}^{-1}$. The biosolids rate of $90 \mathrm{Mg} \cdot \mathrm{ha}^{-1}$ was selected for research purposes only since it is considered an excessive rate for commercial purposes (MataGonzález et al. 2002). Biosolids were of residential origin from New York City. All biosolids were initially produced by an- aerobic digestion, but some batches that did not qualify as Class B were additionally treated (lime-stabilized) with quicklime $(\mathrm{CaO})$ at the Sierra Blanca Ranch to achieve Class B quality. Cattle manure was collected fresh from steers grazing in native pastures on the Sierra Blanca Ranch.

Chemical and bacteriological analyses of biosolids and cattle manure were estimated from 5 samples that were taken immediately after the application to the experimental pots. These analyses were made at the Soil, Water, and Air Testing (SWAT) laboratory of New Mexico State University, Las Cruces, New Mexico. Biosolids TKN was analyzed by the macro Kjeldahl method. The concentrations of P, K, Ca, Mg, S, $\mathrm{Na}$, and heavy metals were obtained using inductively coupled plasma-atomic emission spectrometry (EPA Method 200.7) (USEPA 2001). Electrical conductivity and $\mathrm{pH}$ were determined in a solution extracted from a saturated paste. The bacteriological determination consisted of counts of colony forming units of fecal coliform bacteria by the membrane filter procedure (SM 9222D) (APHA 1998).

The experimental unit was a pot containing 1 plant of either blue grama or black grama. A factorial experiment $(3 \times 3)$ was established by combining 3 organic amendments: anaerobically produced biosolids, lime-stabilized biosolids, and cattle manure at 3 application rates: 0,34 , and $90 \mathrm{dry} \mathrm{Mg} \cdot \mathrm{ha}^{-1}$. As a result, 9 treatments were applied to each species, and each experimental unit was replicated 4 times. The pots were arranged in a completely randomized design within the rainout shelter.

After the application of biosolids and cattle manure, pots were homogeneously watered at $60 \%$ of field capacity. Previous experience (Mata-González et al. 2004) with the same soil guided to select this irrigation level, achieving a moderate and consistent soil water content. Applying moderate levels of water had the objective of more accurately representing the 
predominant dry conditions of the study area. The pots were weekly weighed and irrigated with the necessary amount of water to restore the soil water level. The treatments were maintained for 3 months, after which plants were harvested at ground level, oven dried at $75^{\circ} \mathrm{C}$ for 24 hours, and weighed. Data were analyzed by analysis of variance, and significant differences among treatments were determined at $P<0.05$ by the protected LSD test.

\section{RESULTS AND DISCUSSION}

There was no interaction between amendments and application rates for either blue grama $(P=0.91)$ or black grama $(P=0.10)$. Therefore, the effects of these 2 factors were independent. There were no differences in aboveground biomass production of the 2 grasses $(P=0.90)$ among the 3 organic amendments (Fig. 1). This suggests that no differences in grass growth can be expected by applying any of these amendments to desert grasslands under similar soil water conditions. The levels of $\mathrm{N}, \mathrm{P}$, and $\mathrm{K}$ were very similar in both types of biosolids (Table 1), indicating that their fertilizing effect would be comparable. Cattle manure, however, had only one-fourth of the $\mathrm{N}$ and one-sixth of the $\mathrm{P}$ contained in the biosolids and yet had the same effect as biosolids on plant growth. An important factor that may have influenced this response was the relatively low soil moisture level $(60 \%$ field capacity) at which the plants were maintained. A previous study (Mata-González et al. 2004) reported that the fertilizing effect of biosolids was severely limited by low soil water content (40\% field capacity). Stavast et al. (2005) also reported the effect of manure application to blue grama was restricted

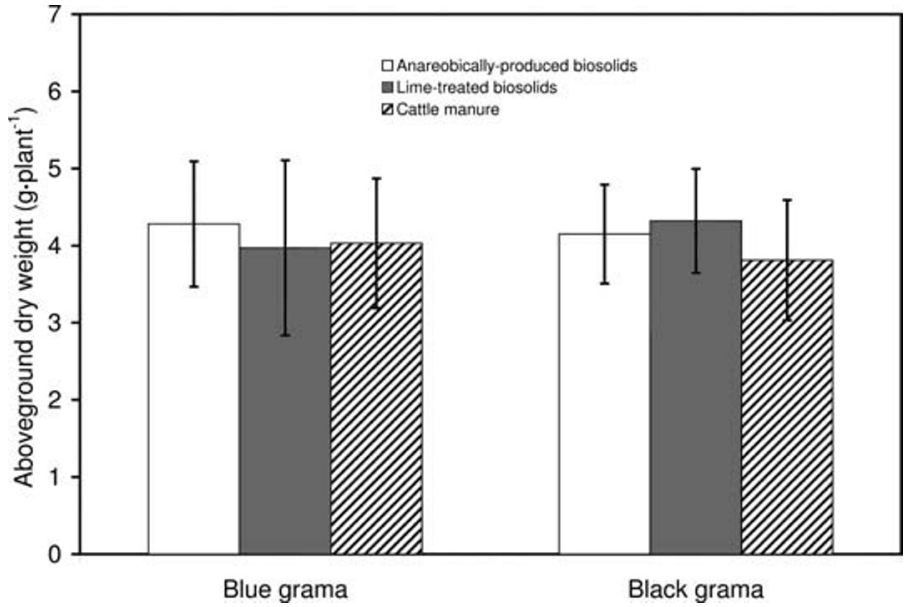

Figure 1. Aboveground dry weight per plant (mean \pm SEM) of blue grama and black grama as affected by application of different types of biosolids and cattle manure irrespective of the rate of application.

by low rainfall. In our study both grasses were apparently water limited and thus unable to benefit from the higher levels of nutrients of biosolids in comparison to manure. Although our study cannot accurately represent field conditions, results suggest that under water-limiting conditions, applying biosolids and manure with different nutrient concentrations would produce similar effects in desert grass production.

Regardless of the type, the application of organic amendments increased aboveground production of both grasses with respect to the control (Fig. 2). Application of $34 \mathrm{Mg} \cdot \mathrm{ha}^{-1}$ was marginally higher $(P=0.07)$ than the control, while application of $90 \mathrm{Mg} \cdot \mathrm{ha}^{-1}$ was higher $(P=0.02)$ than the other 2

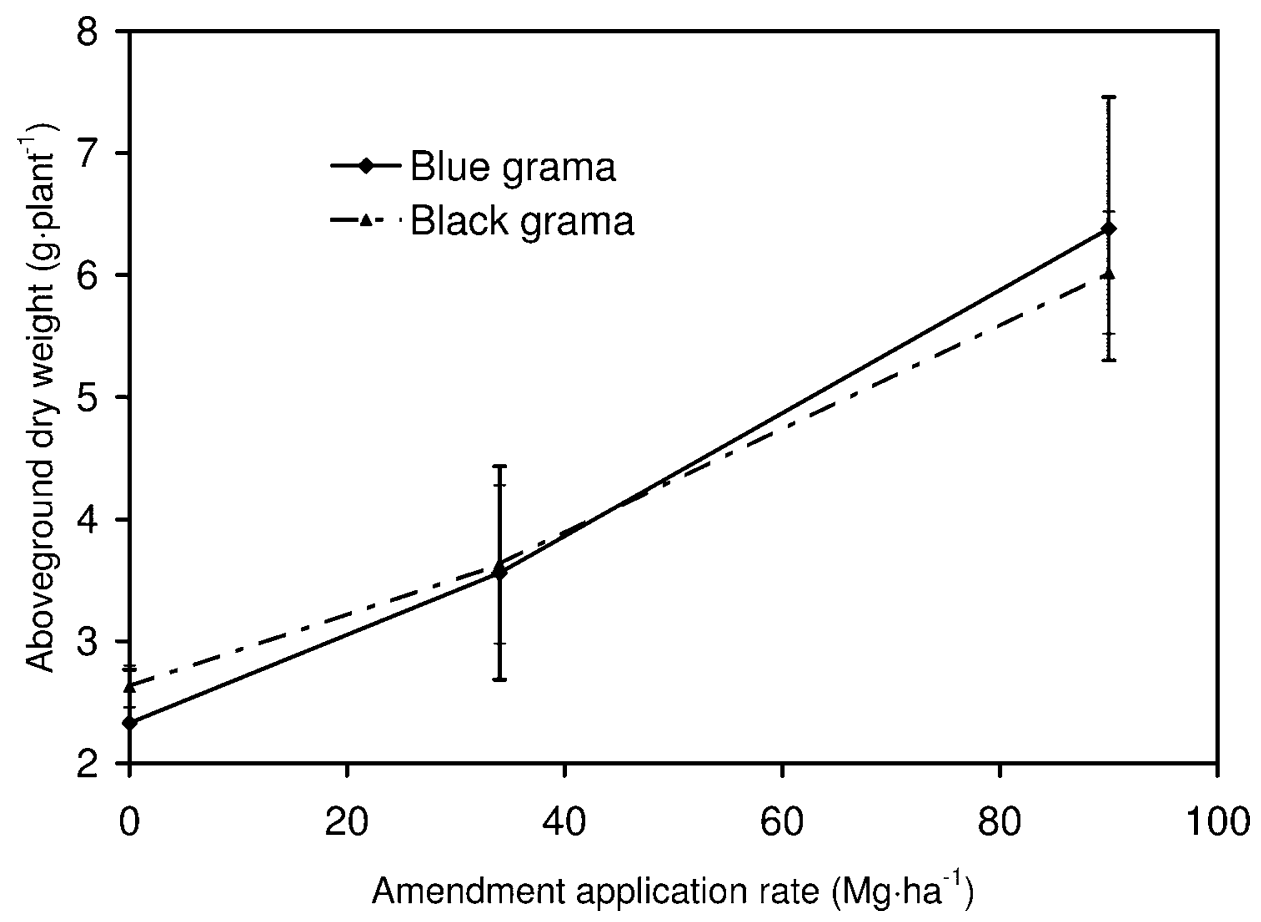

Figure 2. Aboveground dry weight per plant (mean \pm SEM) of blue grama and black grama as affected by application of different rates of organic amendments irrespective of the type of amendment. 
application rates. Aboveground desert grass growth has been previously documented following application of biosolids (Fresquez et al. 1990; Jurado and Wester 2001; Mata-González et al. 2002, 2004) and cattle manure (Stavast et al. 2005), but direct comparisons of these 2 amendments have been lacking (Moss et al. 2002). Root growth was not evaluated in this study, but a previous report (Mata-González et al. 2002) showed that biosolids tend to favor shoot over root production.

Blue grama has frequently been the subject of biosolids and cattle manure studies (Fresquez et al. 1990; Mata-González et al. 2002, 2004; Stavast et al. 2005), but this is the first report of black grama. Our results showed that blue grama and black grama responded similarly to the application of organic amendments, despite indications that black grama could be more responsive to environmental variation than blue grama (Gosz and Gosz 1996).

Despite the benefit of higher levels of $\mathrm{N}$ and $\mathrm{P}$ with respect to manure, biosolids had the disadvantage of higher levels of electrical conductivity and heavy metals (although Cd was equally present in biosolids and manure) (Table 1). Nevertheless, the heavy metal concentrations in both types of biosolids were well within the standards for biosolids of Class A and B (USEPA 1994). Complying with these standards and particularly applying biosolids in arid areas, where low moisture and high $\mathrm{pH}$ restrict heavy metals mobility, contamination of soils and plants is highly unlikely (Fresquez et al. 1990). The application of $90 \mathrm{Mg} \cdot \mathrm{ha}^{-1}$, however, could represent an unacceptable risk (Fresquez et al. 1990). As previously stated, this rate was selected for research purposes only, and it is not recommended for commercial applications (Mata-González et al. 2002).

Cattle manure had much higher levels of fecal coliform bacteria than biosolids (Table 1). In effect, following the USEPA (1994) bacteriological standards for biosolids application, our manure samples would not qualify for land application. However, the levels of pathogens in manure are not strictly regulated as biosolids are, and yet land application of manure is more common and more socially accepted than application of biosolids (Moss et al. 2002). Likely, the public perception toward biosolids application will tend to be more favorable as the safe beneficial use of biosolids increases.

\section{MANAGEMENT IMPLICATIONS}

In summary, our results suggest that in terms of desert grass production, applying anaerobically produced biosolids, lime- stabilized biosolids, and cattle manure may have equivalent beneficial effects. In addition, applying biosolids could be, in bacteriological terms, even safer for human health than applying manure. Our results also warrant field investigation as a step forward in comparing the effect of biosolids and manure on rangelands. Although pot studies provide welldefined environments in which plants grow, conclusions are limited by the transferability of results to field conditions, with much higher environmental variation.

\section{LITERATURE CITED}

Ajwa, H. A., and M. A. Tabatabal. 1994. Decomposition of different organic materials in soils. Biology and Fertility of Soils 18:175-182.

APHA (American Public Health Association). 1998. Standard methods for the examination of water and wastewater. 20th ed. Washington, DC: American Public Health Association.

Fresquez, P. R., R. E. Francis, and G. L. Dennis. 1990. Sewage sludge effects on soil and plant quality in a degraded, semiarid grassland. Journal of Environmental Quality 19:324-329.

Gosz, R. J., AND J. R. Gosz. 1996. Species interactions on the biome transition zone in New Mexico: response of blue grama (Bouteloua gracilis) and black grama (Bouteloua eriopoda) to fire and herbivory. Journal of Arid Environments 34:101-114.

JuRAdo, P., AND D. B. Wester. 2001. Effects of biosolids on tobosagrass growth in the Chihuahuan desert. Journal of Range Management 54:89-95.

Mata-González, R., R. E. Sosebee, and C. Wan. 2002. Shoot and root biomass of desert grasses as affected by application of biosolids. Journal of Arid Environments 50:477-488.

Mata-González, R., R. E. Sosebee, and C. Wan. 2004. Nitrogen in desert grasses as affected by biosolids, their time of application, and soil water content. Arid Land Research and Management 18:385-395.

Moss, L. H., E. Epstein, And T. L. Logan. 2002. Evaluating risks and benefits of soil amendments used in agriculture. Report 99-PUM-1. Alexandria, VA: Water Environment Research Foundation.

Stavast, L. J., T. T. Baker, A. L. Ulery, R. P. Flynn, M. K. Wood, and D. S. Cram. 2005. New Mexico blue grama rangeland response to daily manure application. Rangeland Ecology \& Management 58:423-429.

USePA (United States Environmental Protection Agency). 1994. A plain English guide to the EPA part 503 biosolids rule. EPA832/r-93/003. Washington, DC: US Government Printing Office.

USEPA (United States Environmental Protection Agency). 2000. Alkaline stabilization of biosolids. Biosolids technology fact sheet. EPA 832-F-00-052. Washington, DC: US Government Printing Office.

USePa (United States Environmental Protection Agency). 2001. Method 200.7, trace elements in water, solids, and biosolids by inductively coupled plasma-atomic emission spectrometry. EPA-821-R-01-010. Washington, DC: US Government Printing Office. 